
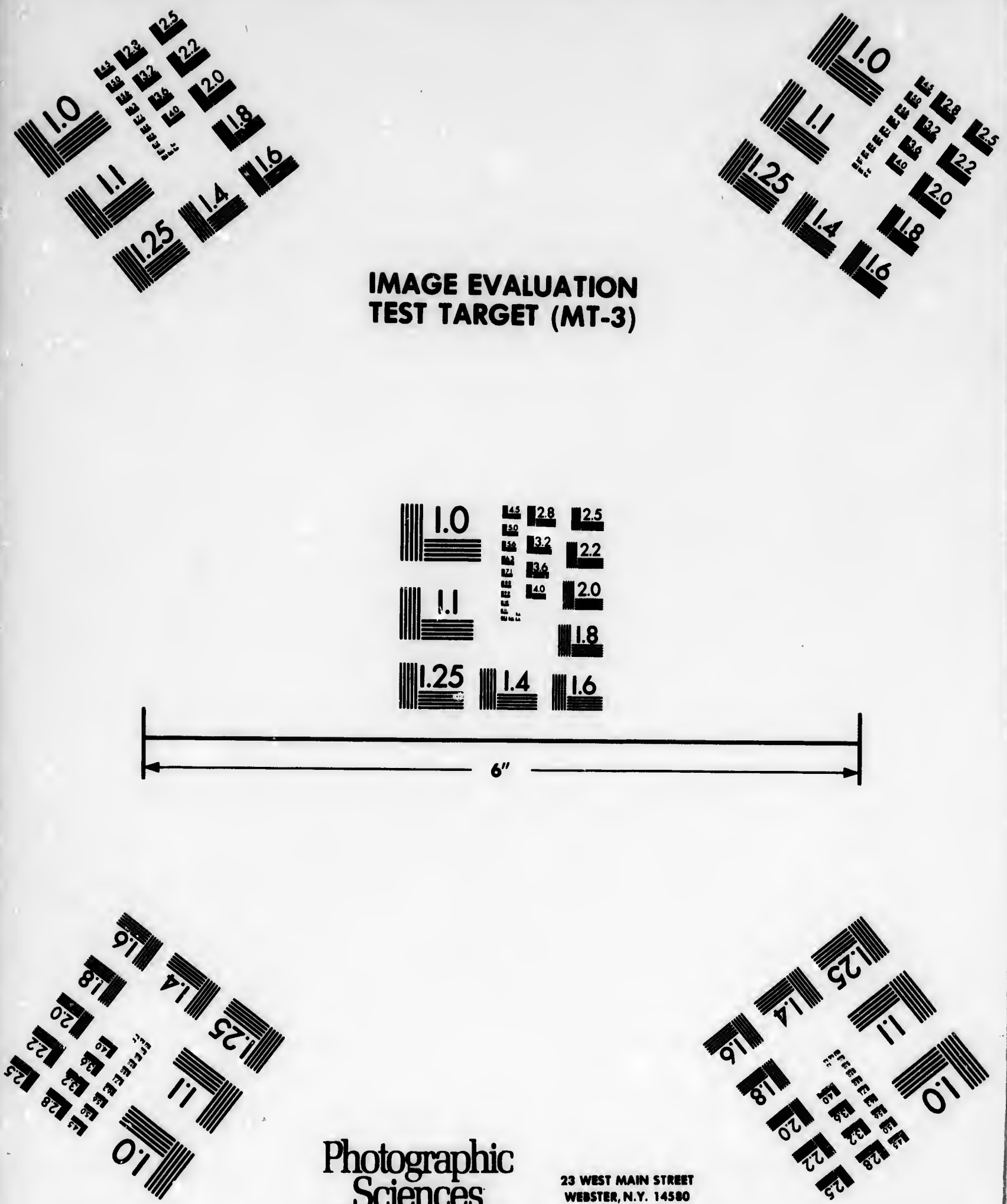

Photographic Sciences Corporation

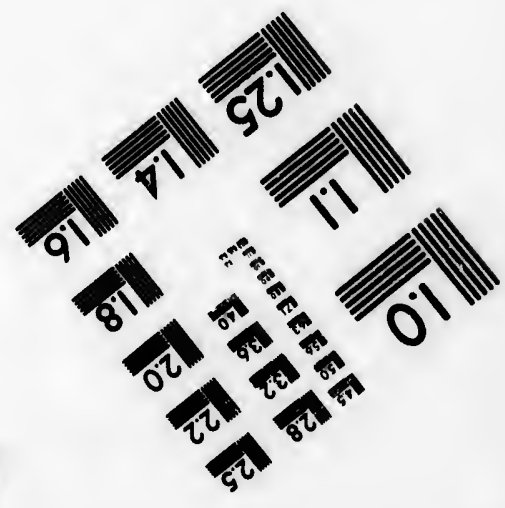



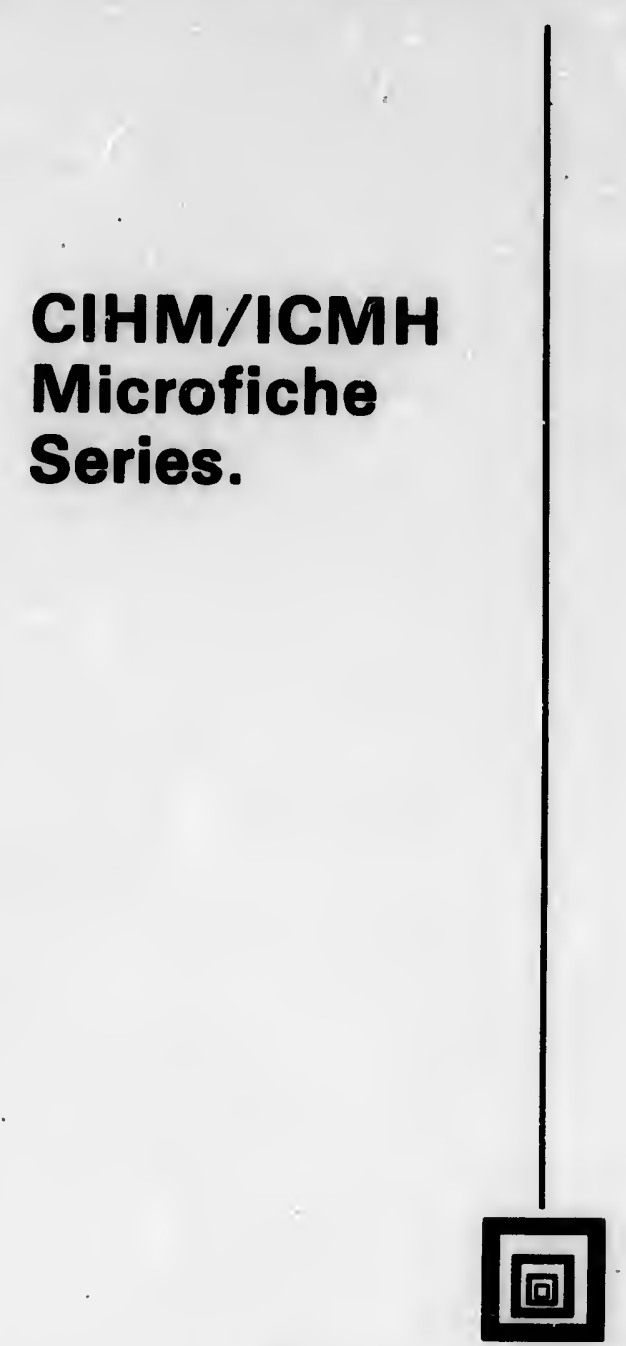

\section{CIHM/ICMH Collection de microfiches.}

Canadian Institute for Historical Microreproductions / Institut canadien de microreproductions historiques
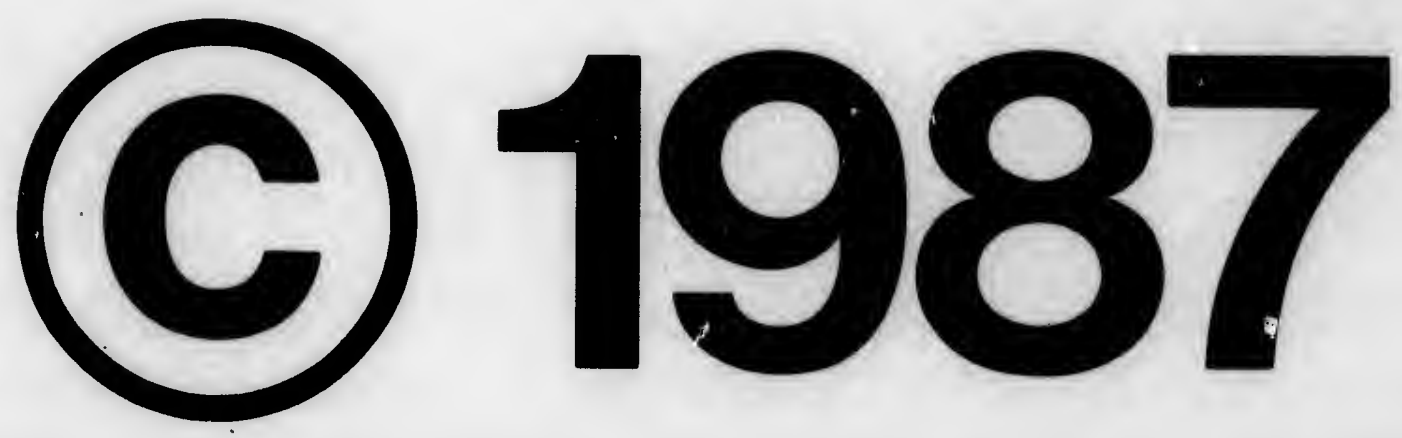
The Institute has attempted to obtain the best original copy avaliable for filming. Foatures of this copy which moy be bibliographically unique. which may aleer any of the images in the reproduction, or which may signifleantly change the usual mothod of fliming. are checked bolow.

Coloured covern/

Couverture de coubur

Covers damagod/

Couverture endommagte

Covers rostored and/or laminated/

Couverture restaurbe ot/ou pelliculise

Cover title missing/

Le titre de couverture menque

Coloured mapar

Cartes glographiques en couleur

Coloured ink (i.e. other than blue or black)

Enere do couleur li.e. autre que bloue ou noirel

Coloured plates and/or illustrations/

Planches ot/ou illuatrations on coubur

Bound with other material/

Relis avec d'sutres documents

Tight binding may cause shodows or distortion along interior margin/

La reliure sorrbe paut causer de l'ombre ou de to distorsion lo long de la meres intbrioure

Blank loaves added during reatoration mey

appear within the text. Whonever possible. these have been omitted from filming

II se pout que certaines pages blanches ajoutdes lors d'une restauration apparaiasent dans io texte. mais, lorsque cele stait possible, ces pages n'ont pae ste filmces.

\section{Additional comments:/}

Commentaires suppiómentaires:
L'Institut - microfilm le maillour exempiaire qu'il lul a stó posulbie de se procurer. Les dotaile de cot oxemplaire qui sont pout-stre uniques du point de vue bibliographique. qui pouvent modifier une image reproduite, ou qui peuvent exiger une modification dans ia mothode normale de filmage sont indiquis el-dessous.

Coloured pages/

Pages de coulour

Pager damaged/

Pages endommagiea

Pages restored and/or laminated/

Pages reataurbes ot/ou pellicuibes

Pages discoloured, stained or foxed/

Pages dicolortes, tachordes ou piqutes

Pages derached/

Pages dótachies

\section{Showthrough/ \\ Transparence}

Quality of print varies/

Qualite incoale de l'impression

Includes supplementery moterial

Comprend du matóriel suppiómentaire

Oniv edition available/

Soule sdition disponible

Pages wholly or partially obscured by errata alips. tissues. otc.. have been refitmed to ensure the best posabib image/ Les pages totaloment ou partiollement obscurcies par un fouillet d'errate. une pelure. orc.. ont té flimbes nouveau de facon obtenir ie meilloure image possible.

This item is filmed at the reduction ratio checked below/ Ce documont est filmb au taux de roduction indiqud ci-dessous.

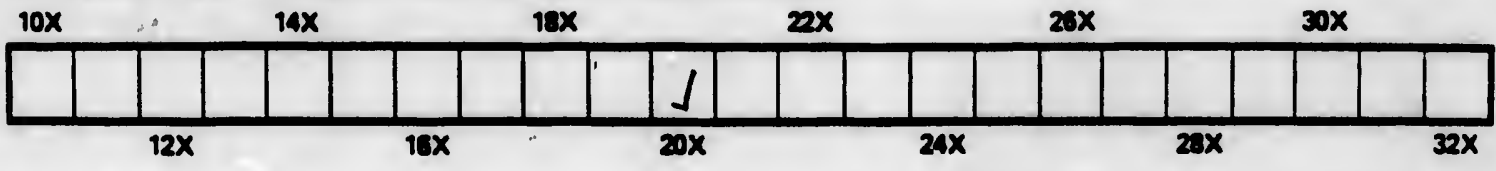


The cepy filmed here hes been reproduced thenke to the generoolty of:

$$
\begin{aligned}
& \text { Douglas Lbrary } \\
& \text { Qusan's! Unlveraity }
\end{aligned}
$$

The Images appocoing here ere the bect qually pocolble condidering the oondtiton and bolbillty of the origind copy and In kceping with tho filming contrect speclifeations.

Original copies In printed peper covere are filmed beginning with the fromt cover and conding on the laot page with o printed or lllucturted impression, or the bock cover when epproprtote. All other origland copies are filmed beoinnine en the first pege whth e printed or Illustrutiod Impreealon, and cnding on the last page with a printed or illustrated Impreasion.

The last recorded freme on cach mlerofiche shall contain the symbol $\longrightarrow$ Imoaning "CON. TINUED"), or the aymbol $\nabla$ (meaning "END"). whichover applies.

Maps, plates, charts, otc., may be filmed ot different reduction ratios. Those too large to be entiroly included in one expocure are filimed beginning in the upper loft hand comor, loft to right and top to bottom, es many frames es required. The following dlagrams lllustrate the mothod:
L'oxempiole films fut reprodult artes o is Exicraitus de:

\section{Dougles Libran Queon's Unluoraity}

Les images euhantes ont che reprodultes avec b plus erend soln, compte tenu de is condition ot do lo nettets de roxomplaire fitine, et en conformits aves les conditions du controt de filmaco.

Les exemplabres criglneux dont la couverture en papier cet imprimse cont filmbe en commengant par lo premier plat ot en terminamt solt par la dernitre pege qul comporto uns emprointo dimpresilen ou dilluotration, colt par la sccond plat, eclon b eas. Tous les eutres oxemplalrea origlnaux eont fitmis en commenpent par la promlite pace qul comporte une emprointo dimprescion ou d'ilustration et en terminent par le dernilire page qul comporte une telle empreinte.

Un des oymboles sulvante apparafter sur is dernitre innes de chaque microficho, solon is cas: b symbolo $\rightarrow$ donifis "A sUIVRẸ". is oymbole $\nabla$ dignitiv "Flse".

Les cartes, planches, tableaux, te., pouvent stre filmbe d des taux de réduction differenti: Loreque lo document eat trop grend pour ctre reproduit on un seul ellohs. II cot films o partir do liangle supiribur gaucho, do eauche a drolte. ot do have on bes, en pronant lo nombre

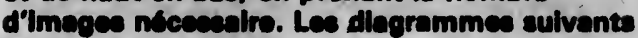
illustrent in mithodo.
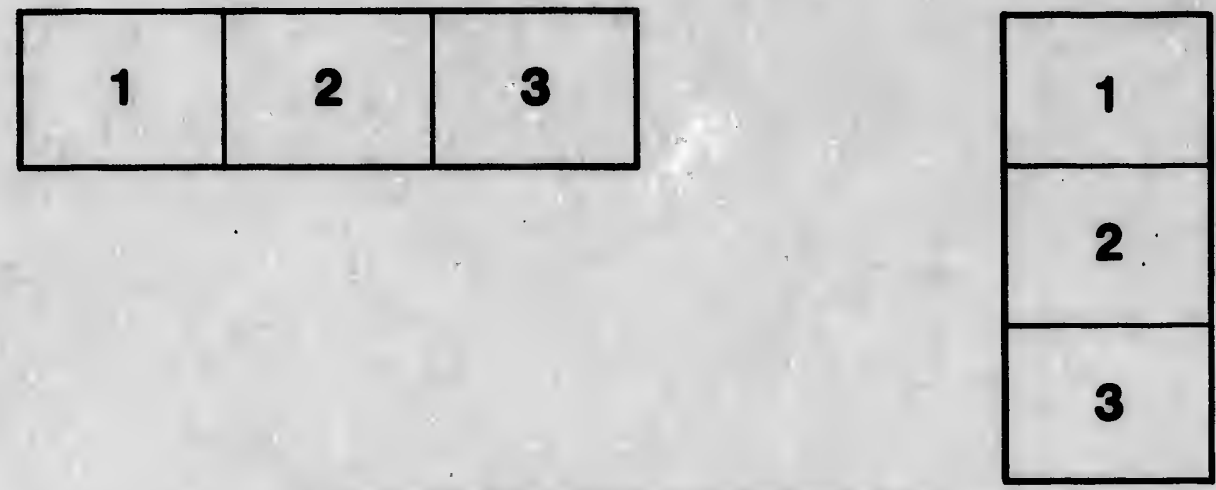

\begin{tabular}{|l|l|l|}
\hline 1 & 2 & 3 \\
\hline 4 & 5 & 6 \\
\hline
\end{tabular}




\title{
SOMEWHAT ABOUT A FEW
}

\section{MEDICINAL PLANTS OF NEW BRUINSWICK.}

\author{
ל. \\ BY DR, DUNCAN, OF BATHURST,
}

The following original paper, contributed by Dr. Duncan, was read before the Natural History Society, on Tuesday Evening, 5th inst.- apre C 1887

\section{Dralla Acerceolla.}

One of the prettlest flowers that growe in our wcods is the Oxalle Acetosella, or " wood correl." No sooner does epring awaken vegetation than, Phoenix like, the wrod norrel resorates the remains of last sosmon's verdure and, under the influence of warmth and sunohine, carpote beneath the shade of the fire with a greenness ail its own.

Take this specimen and let no examine its finely pencilled obaracteristics. In the old Botanists, by rare similitudes and antique but true phrases, ts presented the life-iike features of the plant, free from the technicsities of modern botany. Though unique the language is none the less plain or easily understood. "Wood sorrul is a lowe or base herbe, without atalkes, the leaves do growe from the roote, (overy one atanding on a long foote staike), and, at their firat comming foorth, are - folden together, but afterwarde they spread abroade, and are of a faire greene colonr, in number, three, and fashioned almoat like the trefingl, eaving that each leaf hath a deep olift in the middle," and is heart-shaped, whlch trofoil is not. "Annong these leaves rise up divers slender, weake fuote-stalkes, not arowing above them, with every one of them a flower at the top," "almost unade like little bellew, of a white colour, with purple veynes all alnnget," "or in some danht over with a nmali shew of blush, and in some but on the backe side only." "The foure consisteth of five smeil leaves (petals), after which come little ronnd knape or huskes, full of gellowirh seed." "The roote is very threddy, and of s reddish colour, not perishing in the year, but ablding with some leaves thereon in the winter." So anith Syto's "Dudnene," printed at Antworp, 1578, supplemented by Gerarde and Parkinson. Alongoide this, we may pisco those deccriptive lines of Carlotte Smith -

"Wood sorrel, with its light ereen leaves,

Heart ahaped, and triply folded ; and tis root

Creeping fike beaded coral ;"

and those happy otrokes-

"Trim Oxalie, with her pencill'd flower.

Close to the sheltring copee the inviden cleaves, And coyly plalts her purple-tinted leaves."

These leaves, thus parple-tinted on the under surface, are the old oxidised ones; oceni. onally they are bianched, and at timea variogated white and green. Like clovers, they are sometimes in fours. On the claw of each petal is a yellow spot, five " fairy favours" in all. There are ten stamens a short outer row of five, and a longer inner series opposile the petale. One of these is mayhap the abortive inner coroil noeded, co easy Braun, to perfeot the etructure of the oxalia. The sepals, five in number, equal and persistent, are in dry aitu. ations converted into leaves. These miniature leaves are jointed on to red iweilings, which are repetitions of the scales of the root-atem, and appear capable of propagating the plant in oircumstances unfavorable for the prodnction of seed. There are five styles pencilled at the apex or oapitate. The ceed-vencel seatters its contents in a remarkable - manner. Whon ripe, the fruit, a membranenus pod, erecto itcolf straight, and the ellighteat touch, oven the wind, makes the soedo fir aronad, reminding 
Ode closely of the Impatiens fulva or "spotted touoh-me-not." The capanle io a pentagon having 5 ceils and 5 valves, opening lengthwise and, with elesticity, down the ourners, each cell cuntaining one or two enmpressed etriated eeds, which are arillated. The white fleahy sril, (or outer integument of the seed) ringed like a oaterpiliar, curls back at the maturity of the fruit and jerks the seed to some distance, sometimes acoompanying it, and, after touch. ing the ground, again rebounds and sends the ombryotio plant, like an "April fool," "further on." Thus providing treeh eoil not otherwise easily obtainable. What is commoniy called the root is simply an underground creeping stem (rhizoma) and fleshy knobs that stud it are either the bases of fallen leaves or single bud-acales, giving origin to lateral buds, which like the terminal one, increase the network by which the plant is ever burn anew.

The leaflets, like those of the Mimosa pudica or Sensitive plant, possere the remarkable property of self-moving. When those which are spread in a horizontal position, are atroked upwarde or are preseen upon st the base they gradually droop. The same thing is noticed after plucking a portion of the piant. If placed in water some time elapses before it recovers its composure and permits the leaflets to again expand. An exotio species of Oxalio, the Oxcalis sensitiva, is on remarkably irritable that its leaves contract at the gentlest touch, and is for this remeon held in superstitious veneration in the Eust Indies, the priests employing it in their megio rites and as a charm against diseases too powerful for their skill. It has been observed that most of such plantes irritables are acid. An old writer remarks that the "leaflete close against rain," and another has it that "the leaves shut before rain and when it is fair open again." Linnæua, however, says they expand in rainy and con tract in dry weather. At no time certsinly have I observed the leaves more horizuntal than in rain, the fow that remained drooped, appearing to be influenced by the dry soil and had not yet been gladdened by a draukht of nature's cerdial. This is, as might be expected, in spite of Pliny's dictum to the contrary. Among his "Prognostics Tempestiva" he enumerates: "Trifolium queque inhorrescere, et folis tempeststum subrigere certum est."

The sleep of the leaves is best observed by removing a portion of the plant into the house and placing it in water, when the leaflets will be seen to droop in rest at night.

The little white flower with its delicate purplish veing is a Sun Worshipper, following it during the day and lonking towards it ere it sete, paye homege by folding up ite blossom. It is also a good natural Hygrometer. This was noticed by Linneus, who in his "Tour in Lapland" remarka : "Here also grew Hepatica and Woodsorrel. Their blossome were all closed. Who has endowed plants with intelligence to shut themselves up at the approsch of rain? Even when the weather ohangee from ennohine to rain, though before expanded, they immedistely cluse." An old botanist, Fuchoius by name, states that, not only in his own experfence, but in that of many others, an abundance of flowers in this plant foretoken: onploue rains and inundations for that $j \in a r$, if fow, a drought. Iast spring and throuphiut the whole year till lute in autumn the Oxalis Acetosella flowered in abundance, bence, no duubt, the late floode and inundations.

The wood sorrel chooses nurthern exposures and shady cool woids, partioularly those of pine and 6 , where the light avil gives free access to its suckers. It lives alwo the mouldering trunks and roots of old trees, beautifying them in their decline and fall. It is everpwhere plentiful aruund Bathuret, and flowers in June. It is found ali over the northern regions of North Amerlca, Lake Superior, northerwardn, south to the Allegbanies, and gladdens the botanist of Europe, equelly in Lapland and the Alpa, in the beath-clar Cheviote (hence not confined to wingda) There is a pretty pink variety, which $I$ have neen several times. It is the variety "Alures purpures" in Kay's Synopgis. Camerarius considered this to be male und the white the female plant-0 little were the sexes in planta known to the older writers. Do Candolle mentions a blue variety.

It has long been in wac as a aslucl. Dr. Wm. Turner, one of the earlist English butanista, $(1562$,$) reckoned it "very gund tis make aslettee$ of." Linnwus avers that the acidity of the leaves is more agreeable and lelicate than that of lemon. Phillp Miller recommends a border of it in every kitchen gardew.

From an early period wond sorrel has been a member of the Materia Medica. It is describer as refrigerant, antiscorbutic, diuretio and antiseptic. Of its stomachic effects meution is marle as far back as Pling, whum Gerarde thus paraphrases "S.urroll "iu Buis or wisud surrell, stamperl and used for green sauce, is good for them that have sick and feeble stomachs; for it ntrengtheneth the stomache, procurerh appetite, and of all sorrel sauces is the best, nut onely in vertue but also in pleusantnesse of his taste." It is still nser on the continent of Europe as a fish sance, and as a substiunte for lemonsde. From ths lugfets resemh. ling the heart it has been regarded as a cardiac, but, like most Frenchmen arutund Bathurst the old physicians appear to have confounded heart and stomach, so that what comforted the nne cheered the other. The oractitioners of Germany write, that "the distilled water of Alleiuga cooleth well and comfirteth the heart, and quencheth thirst and that it is gond in all hote diseaves and infarmmations. They hold also that the distilled water of Wond Sorrel is good to be tounpered with alumn for the wounds and sores of the mouthe." Infused in milk, to form whey, or as a tes it is said to be used in putrid and other fevers with good unccess. The leaves and stalka, wrapped in a cabbage leaf and macerated in warm ashes until rerluced to pulp, have been applied to scrofulous anres. It is recommended by $W$. H. Taylor (Lancet, June 5th, 1869), as extraordinarily efficacious in scurvy, having effected curee after lemon-juice had failed. The fresh plant may be eaten raw, or 4 graine of the Quadroxalate of Putash, ealt obtaived from its expressed juice, may be used three times day. 
The julce radriens vegetable blues, congu. lates milk and inatantly preolpitates lime from it solutions. It owee its soidity to the euper or Binoscalate of Potash, which is cryotalised from the expressed juice, and sold as "Essential salt of Lemons." 'The French nome it "Salt of Surrel." Like Oxalio Acid it is poimnnus. It is frequently (very I may truly say) anlulterated with Crusm of Turtar and, sumtimes, Sulphurio Acid or Vitriol and Cream of 'l'artar are subutituted for it. It is used to take iron moulds and ink stains out of linen, and as a tent fur the presence of lime

The Wood S rrel is now pretty generally considerei to be the unvient Irisb shamrock, intu au examiuation of its olaius, juwever, I shall not euter.

The Generio name Oxalis, adupted by Lin. nosus, did not belong to this plant, but was given to a epeoies of Duck by Dioscorides. Pliny's nsme, Oxys, whieh like Oxalis, means sharp-pointerl or wetuphorically acid, ur ouur, is that made use of by the older intaniats. Acetosella (little ourrel), preserved in the French "Is petite useille," seews to have been used by the Pharmacinceias, in order to diatinguiah it froun Acitusa the sorrel priper. It bears the gane name in Gorman, Fivuch, Spaniah aud Italian, and amung nicknames may be men. tiuned " C'uckoo's bread," "Gowk's meat," (Scintch) "Woodsour," "Stubwourt" - from its krowiog on old route and ktumps (stubs), and "Alleluya"-one of its ildest Inglish numes, given to it in Ruman Cathulic times, owing to its appearing in bluseum butween E:sater and Whitsunticle, the sousou at which the Pasimg endiug with thut word were oung. The Welnh call the flivers, "Iuiry belle," and beliove that they ring the merry yeals which call the elves to "mounlight dance aud revolry." "Whonce hast thin won thy numes thou winple fl iwer?" "Thin anclent, solemn title, sure was given, Pale Alleluia, by gruy munks of uld.

What time the chauterl servloe russ to Heaven, When paced the bretheru furth, barefuut and stoled.

Tu f tr-uff tanes in h zary torest bid.

Where pealiug belly for Buster masses runy.

-It chanced upou tho goud st. Patrick's Day, $A$ warrlor, wounded, fell with riven crest: Thy llttle carelese plant bluomed where he lay, And hupe reviving ept:ag withlu his breast. 'Dirin-gu-brayh'-lie slnek'd the trefuli'd stem, And vun'd a vow by huly Patrick'ashrine, A shramrock chuplet for a diadem.

Erin's, greeu Erin's burnish'd helm should twine. Then came so 110 vlliaxe leech, down-bent and old, Aud pluced thee in his widely-kather'd stirt.1

Though lung he mused upon thy heallng power, The names ne wave-unoouth they were and rude; 'stubroort' he coll'd thee, 'Ocalis,' Woodsour, Thut by bls aklil the ourling draught imbued. 'I he unlearn'd peasant I ives thy fragile furm, And Gipey children soek thy mossy bed, When daj are long, and April suise are warm, 'T hey laukh and say, thou art 'The Cuckoo's Bread." "

Anemone nemorosa-Wood Anemome. Ot epring favorites rone prettier than the "Coursgeous windfluwer, lovellest of the frail."

Nut ou oymmetrically leaved as the oxalin, by its greater size and the prufusion of it blussutne, it catches the eye more readily. What more attractive sight then a bank robed in white Anemones - the "flor otella," flural utar of the Italians. A bappy fancy caught by Chariotto Smith -

There, thlokly otrewn in woodiand bowers, Anemones thulr utare unfold."

And Mrs. Hemans-

"Dust thou reo," ohe anks-

"Where wuthern winds firat make their vernal ulnging,

The atur-gleam of the Wood Anemone

The flowere give out their fragrance, thuught by some to be as chnice 20 that of the viola oilorats, tis the roving wind, which wantonly scatters it abruad, infurming us of their presenoe, long befure seen.

Let us examine the specimen. Like the Oxalis it is perennial with single radical leaves. Thnse of the stern, three together, whorled, forming an involuere remote from the flower (which it apetalong), and by long petiuled, three divided. tonthed and cut : the lateral divininns often two parted (variquinquo folia). The sepals, 4 to 7 in number, sre oval, white - the psle anemune-sumetimes tinged with purple outaide, 80 that though at firnt plain louking, it gathers fresher tints as it ustures and at length wears o olush of beanty on its undest cheok, uracefully pondunt as they "wait the breathing of the wind." The sepals "cluse together in raing weather, and the flower hangs dowrwarde" to "shun the iupending shower." At tiunes may be noticed one of the sepsla partially or wholly converted into green leaf; and flower-stein in ite development upwards will now and then steal away one of the triple leuflets of the involucre, and wear it as a trouhy under the seed-carpels It is said that purple varieties are common. Blue and double varieties ubiund near Wimbledon, of "Kulspure" faine, bue I heve neicher seen nor beari of their being seen in New Brunewick. The blue species-Anemone Appennina froquents the grisver and thickets of Italy. During sume seasons there is quite scaroity of blussint, genersily due to druukht, but sometimes due aleu to the unpreparedness of the ront-stuck after particular eeasuns, to prodece a flower-stein. The root-stock is like a piece of atick desd at one end. It creeps "lung wise under the upper crust of the ground, opreading out it divers small knobs like branohes, of a dark brown oulor outside," and s sectinn show. ing "white within." According to Braun it prolonge its eubterranean growth, with alternations of lesves and buil-scales fur several years before it arrives at a fluwer terminatlng the sheot. "The number of annual bud-ecales on the horizuntal root-stock incresses from year to year, rising gradually to 8, and each of these preparatory sections terminate with a single lung-stalked leaf, till, finally, the last section, after producing ite proper number of bud. scales, rises into an erect ebaft, producing the three-leaved whorle of stem lesves and the nod. ding flower." How very little do we think, while beedlessiy plucking one of the blossoms, that, by 80 doing, we in a moment destroy the elaborate preparation of yeare! This explalne why, when under cultivation. in our gardene the plant cannot bear to be much shifted, and 
why it dnes not flower freely or In perfection unless loft to extend iteolf undisturbed.

Eabitath - The wood anemone flourished from Canada to Carolina, ond on both sides of the Rocky Mountalns. Though found in abundance around Bathurst, it is some. what rare in our nurthern counties, and more common in the southern ones. It profers the mergins of woods and flowers with the coming of the swallow in May. The varloty with the lesves tive partito (a quinquefolia) ranges from Virginis to near Lake Winnipeg. This plant is fairly ecattered over Europe, be. ing equally well known in Grest Britain and France an in Germany and the Swiss Alps. Einglish poots write lovingly of the "frail and fair enemone." Thus writes Merritt :

"The queen of upring flowers- wood anemone, In sylph.like pride:

I love thet flower, mout delicatoly fair,

So fondly bending on her slender stay,

A thougb in love with her own leaves; and where In field or grove

Bo leaves so exquiditely wrought as they iChaplet for love."

Our own poets admire it ho less warmily. Thus Hoffmen longs for "The breese that calls

The Wind-flower by the hiliside rill,"

to lift the tresses from his true-love's cheek,

"And let me see the bluah diviue;"

for who doubts thet our "ladies faire" have,as Bryant puts it.

s" Eres that shame tbe violet,

Or the dark drop that on the panay lies,

And foreheads white as when in cluaters eot

The anemones by forest fountalus rise;

And the spring beauly bosate no tenderer atreat

Than the ouft red on many a youthful cheek."

\section{NAMES.}

"Anemane" occurs in Hippocrates and Dios. corides. It is derived from the Greek "Anemoe," the wind,for the "floure doth never open itselfe but when the wiode doth blnw,"as Pliny writes, or, in the worde of Horace Smith.

"The coy anemone, that ne'er uncloses

Her lipe untll they re blown on by the winds."

According to an ancient legend the anemone is ssid to have sprung from the tesrs shed by the Goddess of Love when ohe wept o'er the body of Adonis :

"Alas the Paphien ! Fair Adonis elain !

Tears, pleuteous ag his blood she pours amain;

But gentle flowers are born and bloom around

From every drop that falle unon the ground:

Where streams bis blood there blusbing spring. the rose,

and where s tear has dropped a Wind-flower blows."

-Blon's Idyl.

It is donbtful if our Anemone is the same as the classical one. It is applicable, however, to plants of eeveral different geners under present arrangements. Dr. Prior thinks it was the Cistus or rock-rose. The specitio term nernorosa (in the sense of pertaining to a wood), is found in the Ranunculus nemorasus of Fuchslng. The Frenuh still retain the sense-s relic doubtless of some anoient impress given to popular opinion-in the pretty term Sylvie. The Anemone of Dioscorides, whatever it was, be commends for ocular diceaces, an does Pliny and Gulen. Our plant has inherited part of lt: virtuew, otherwise the Germans would not have termed it "augen wurtz eye-herb," 1.0. , and

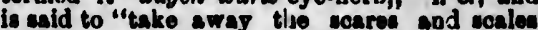
which grow on the eyes." It is aleo called in Germsn "stork flower," bath heing equaily ball. ad as the harbinger of opring;"

In anolent times the snemone had a great reputation for it medical propertice. Magioi. ans ordered every person to gather the firmt they saw in the year, at the same the repeating the fullowing formuls:"I gather thee for a remedy againat dibease." It was then oarefully preserved, and in the event of the gatherer beilog ill was tied around his neck or arm, as this was supposed to drive sway the malady. The leaves possess such an acridity, resembling in this reapeot other Ranunculaces, ss to be in some inessure poisonous. They have been nsed as a substitute for Uantharides in raising blisters, "producios not only a more apeedy, but less painfu! efiect" (Willich). It is said to act as a poisou to cattle, produoing bloody urine and convulaione. Cows naturally rejeot the plant, bint eat it inadvertentiy when shifted from the flelds to the woodisnd pastures, where it is common. It is atated to have proved a speedy cure fur Tinea Capitis or Scalled Hesd, ihe bruised lesves be. ing applied twice daily. The active prinoiple of the Anemone is Anemonine, a champhur-ilike crystalline body. It is colorlese and hining, tasteless and neutral, and posnesses powerful toxio properties. Anemonine is found slso in Anemone pulsatilla Anemone pratensis, Ranunculus Filammula; $\boldsymbol{R}$. sceler. atus, and $\boldsymbol{R}$. bulhoous. In hsif til one kraln doses it is very useful in irritstive, cough, asthms, snd whonping cuugh. It is a favorite remedy of the Homeopathists (as Pulartilia) and exerts an alterative influence on the mucus membrane generally, rendering it ueeful in ophthalinic csses, in catarrhal inf unmatlon of the nustrils, throat and respiratory passanes.

It was my intention, when I began this psper, to have included in it a larger number of plants; and harl seleoterl for the purpose, among others, the "Sundew"-Drosera rolundifolia, the new and successful remedy for whooping cough, and whose digestive properties are now well known since Darwis's observations on it, and "Eyebright" - Euphrasia officinalis, a pupular remedy in disesses of the eje, and alnost a apecitio in acute nasal catarrb (cold in the head), a few drops of the tincture, taken at the onset of the affection and repeated every two hours, cutting it short; but my leibure moments in the midst of a large country practice, have been oo few and far between, that up the last minute I have only sucoeeded in completing the foregoing. I have not treated the subject from \& purely medicinal standpoint, trusting in that way to make it rather more interesting to 8 not al together professional audience. Should my remarke be the means of stirring up an interest in our "weeds" pupulerly an called, en many of which are of considersble value in combstting disease, I shsil feel amply rep.id for the time spent on this. 


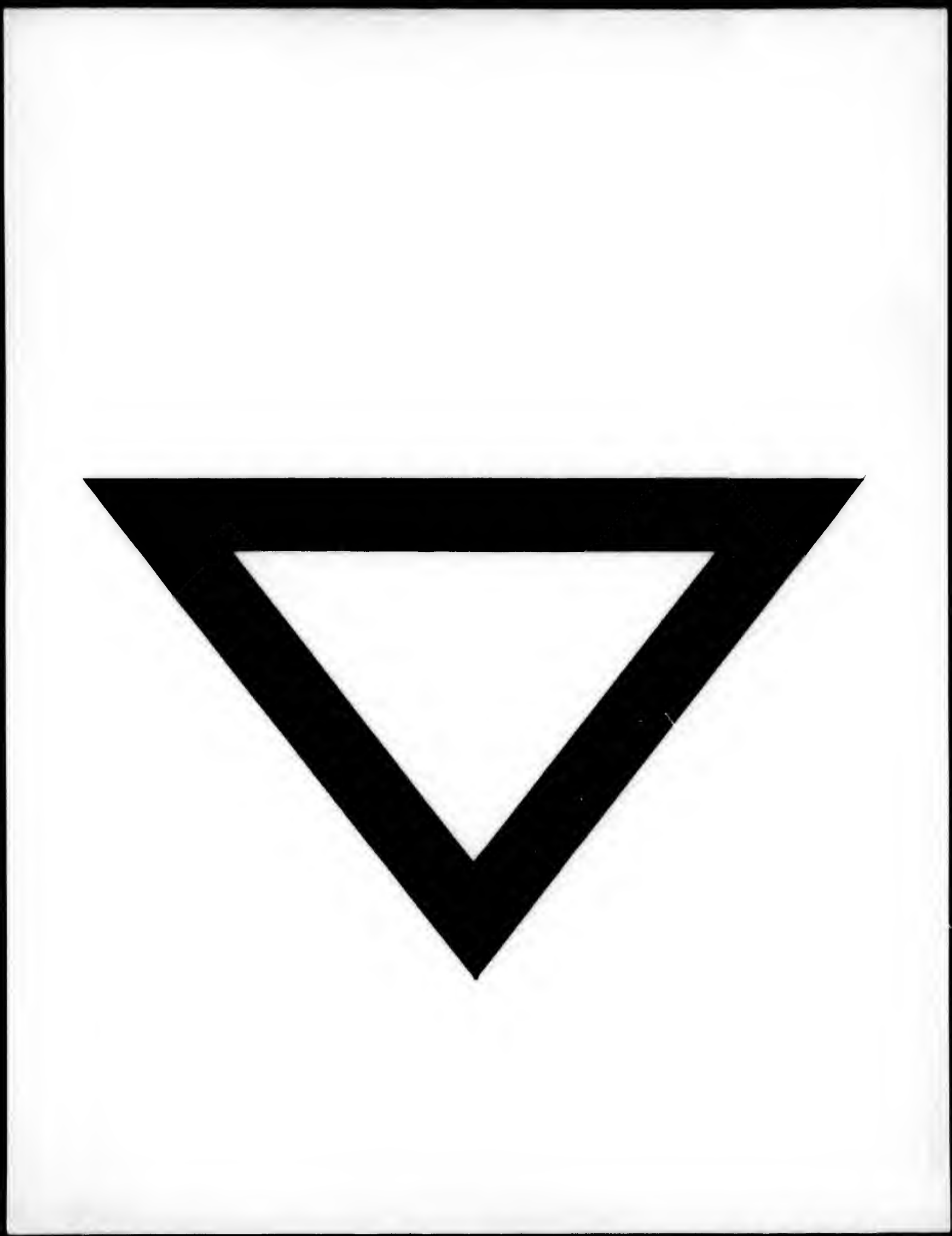

